\title{
Reservoir Characterization of the Early Jurassic Butmah Formation Using Well Log Data in Selected Wells from Iraqi Kurdistan Region
}

\author{
Hawar A. Zangana1, Govand H. Sherwani2*, Yahya J. Tawfeeq ${ }^{3}$, Nadhir Al-Ansari4* \\ ${ }^{1}$ Department of Petroleum and Energy Engineering, Sulaimani Polytechnic University, Sulaimani, Kurdistan Region, Iraq \\ ${ }^{2}$ Department of Civil Engineering, Cihan University-Erbil, Erbil, Kurdistan Region, Iraq \\ ${ }^{3}$ Department of Petroleum Engineering, Kirkuk University, Kirkuk, Iraq \\ ${ }^{4}$ Lulea University of Technology, Lulea, Sweden \\ Email: hawar.anwar@spu.edu.iq, *govand.sherwani@cihanuniversity.edu.iq, yahyapetroleum@uokirkuk.edu.iq, \\ *nadhir.alansari@ltu.se
}

How to cite this paper: Zangana, H.A., Sherwani, G.H., Tawfeeq, Y.J. and Al-Ansari, N. (2020) Reservoir Characterization of the Early Jurassic Butmah Formation Using Well Log Data in Selected Wells from Iraqi Kurdistan Region. Open Journal of Geology, 10, 1173-1188.

https://doi.org/10.4236/ojg.2020.1012057

Received: November 23, 2020

Accepted: December 14, 2020

Published: December 17, 2020

Copyright $\odot 2020$ by author(s) and Scientific Research Publishing Inc. This work is licensed under the Creative Commons Attribution International License (CC BY 4.0).

http://creativecommons.org/licenses/by/4.0/

(c) (i) Open Access

\begin{abstract}
The reservoir characterization of Butmah Formation (Early Jurassic) was studied in two wells: (AT-1) and (SH-1B) from Atrush and Shaikhan Oilfields respectively, in Iraqi Kurdistan Region. Well logs including; sonic, density, neutron, gamma ray, and resistivity, were employed to investigate the formation. The petrophysical properties, such as lithology, shale volume, porosity, water saturation, hydrocarbon saturation, and bulk water volume, were estimated using Interactive Petrophysics Software (IP). Water saturation, bulk volume of water, residual hydrocarbon, and movable hydrocarbon were plotted as Computer Processed Interpretation (CPI) for Butmah Formation in the studied wells. In order to check reliability of log data, lithology of the formation was detected using neutron-density cross plot and $\mathrm{M}-\mathrm{N}$ cross plot. The results of log interpretation display that Butmah Formation is composed of dolomite, limestone with anhydrite and shale in the studied wells. The calculated shale volume shows low clay content. Therefore, Butmah Formation is considered as a clean formation in both wells. Porosity was estimated using porosity logs (sonic, density, and neutron) and had the average total porosity of $(7 \%-8 \%)$ in the two wells. Based on the determined petrophysical properties, particularly porosity and hydrocarbon saturation, it can be concluded that Butmah Formation seems potentially good in reserving oil.
\end{abstract}

\section{Keywords}

Butmah, Carbonate, Reservoir, Interactive Petrophysics, Iraqi Kurdistan Region 


\section{Introduction}

Reservoir characterization is an important aspect in petroleum geology and engineering. It deals with construction of realistic image of petrophysical properties to be used to predict reservoir performance [1]. The present study aims to testify the reservoir potential of one of the Early Jurassic stratigraphic units, which is Butmah Formation.

The study focuses on reservoir parameters of that formation in two exploration wells from Northern Iraq; Atrush-1 (AT-1) and Shaikhan-1B (SH-1B). These parameters, including, lithology, shale volume, porosity, and fluid saturation, can be estimated using log data for un-cored intervals of reservoir rocks.

The formation displays heterogeneous lithology, comprised of three units or parts. In the type section, the upper part $(200 \mathrm{~m})$, consists of oolitic, and detrital limestone with layers of argillaceous limestone, shale, and anhydrite. The middle part $(180 \mathrm{~m})$ is oolitic limestone, argillaceous and dolomitic limestone with sandstone and shale beds. The lower part $(120 \mathrm{~m})$ is composed of limestone and bedded anhydrite [2] [3].

Nairn and Alsharhan [4] discussed sedimentary basins and petroleum geology of the Middle East, and included Butmah Formation within the Early Jurassic, and assumed that Butmah Formation is a minor oil reservoir that produced in Sufaya Field. This reservoir is sealed by anhydrite bed of the overlying Adaiyah Formation (Table 1). [5] had, in a general prospect, studied petroleum systems of Iraq. They assumed that carbonates of the uppermost Butmah Formation may have reservoir potential, particularly when oolitic or dolomitic facies occur, minor seals may also occur within evaporite and shale beds in the upper part of Butmah Formation.

Sherwani and Zangana [6] studied few subsurface sections in Duhok Area, focusing on reservoir characters of three Early Jurassic formations (Adaiyah, Mus, and Alan). The current research stands as a continuation of that study, as it deals with Butmah Formation which is the older unit of Early Jurassic (Table 1).

Table 1. Stratigraphic units of Early Jurassic in Iraq, showing Butmah Formation (Light blue shaded) (After [6]).

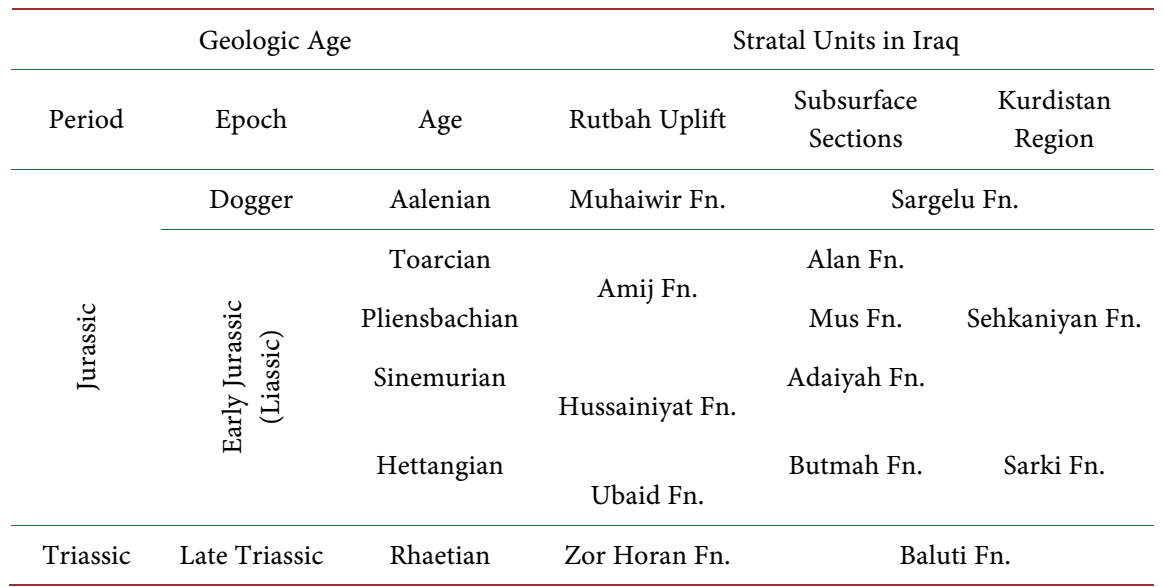




\section{Study Area}

Butmah Formation is a stratigraphic unit that belongs to Early Jurassic Epoch that attracted attention of researchers in the last few years, either as potential source rocks or reservoirs in different parts of Iraq (Table 1).

Two wells are chosen for the current study of Butmah Formation including well Atrush-1 (AT-1) and Shaikhan-1B (SH-1B) in Atrush and Shaikhan oil field respectively (Figure 1). These wells are located near Duhok Governorate, Northwest Iraq. The well AT-1 is an exploration well in the Atrush structure. The well AT-1 penetrated all Jurassic and Upper part of the Triassic successions with a total depth of $3400 \mathrm{~m}$. The Butmah Formation, in well AT-1, is penetrated at depth of $1458 \mathrm{~m}$ with total thickness of $702.4 \mathrm{~m}$. The well SH-1B is also an exploration well in the Shaikan structure. It penetrated all Cretaceous, Jurassic and Upper part of the Triassic successions with a total depth of $2950 \mathrm{~m}$. In well $\mathrm{SH}-1 \mathrm{~B}$, the formation appears at depth of $1772 \mathrm{~m}$ with total thickness approaching $529.5 \mathrm{~m}$, while in its type section (well Butmah-2), the thickness declines to $500 \mathrm{~m}$.

\section{Materials and Methods}

In this study, well logs were the main source of data. The log data of the two

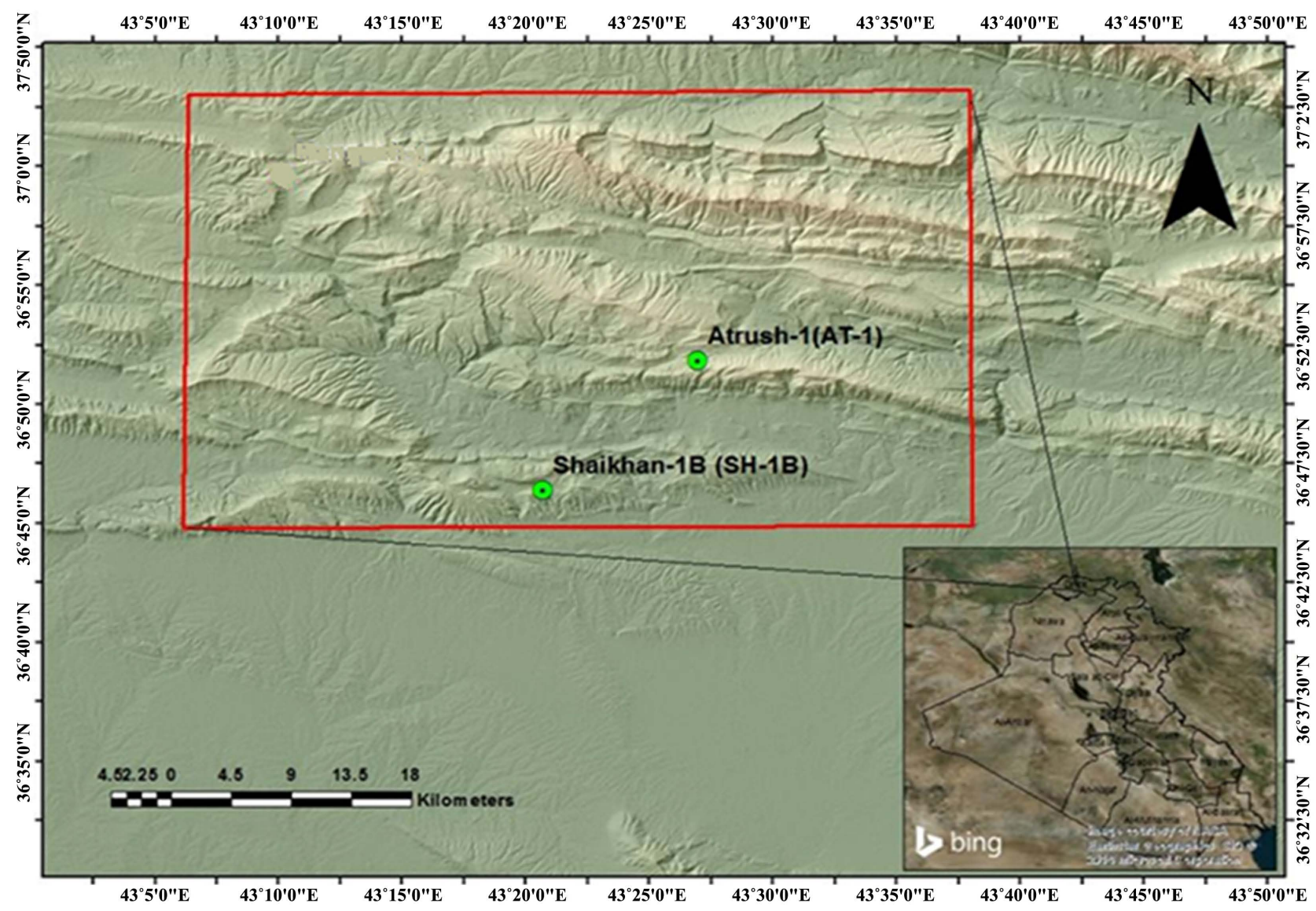

Figure 1. Location map of the studied wells (from ArcMap). 
studied wells were recorded in LAS format. The methods of study were focused on defining petrophysical properties that can detect whether the formation can make a reservoir or not. This was executed through the followings:

1) Using Interactive Petrophysics Software (IP) to process log data leading to estimation of petrophysical properties.

2) Determination of lithology of reservoir rock via neutron-density and M-N cross plots.

3) Utilizing Gamma Ray log to calculate shale volume $\left(V_{s h}\right)$.

4) Total porosity, effective porosity and secondary porosity were measured by porosity logs (sonic, density, and neutron).

5) Using the relevant Archie's equation on resistivity log data to calculate fluid (water and oil) saturation.

\section{Results and Discussion}

\subsection{Determination of Lithology}

Among many techniques, the following two methods were chosen in the current study for determination the lithology of stratal units:

The neutron-density cross plot

This is considered an important and widely used technique for determining the formation lithology. This method implies plotting neutron porosity $\left(\varphi_{N}\right)$ versus density $\left(\rho_{b}\right)$ on a standard plot. The neutron log detects amount of hydrogen in formation, which is related to porosity, whereas density log enables measuring bulk density [7]. When neutron and density logs are combined, lithology can be revealed [8]. The neutron-density cross plot manifests three lithology lines pertinent to three rock types; sandstone, limestone, and dolomite. These lines are marked with porosity values, the log values for a specific depth are plotted on the cross plot to create a point. The location of each point, with respect to the lithology lines, is an indication of lithology and porosity of that point. When a point falls between two lines, this can be attributed to a mixture of the lithologies of these two lines [9].

The neutron-density cross plot of Butmah Formation (Figure 2, Figure 3) exposed dolomite, limestone with anhydrite and shale in the two wells; the porosity ranges from $(0 \%-15 \%)$ in wells AT- 1 and $\mathrm{SH}-1 \mathrm{~B}$.

\section{Cross Plot for Mineral Identification}

The M-N cross plot is widely used technique that deals with formations of complex lithologies. This technique involves sonic log along with neutron and density logs. These logs are employed to calculate the lithology-dependent variables $(M$ and $N)$ that are independent of matrix porosity [7]. The $M$ and $N$ values are calculated by the following equations of [10]:

$$
\begin{gathered}
M=\frac{\Delta t_{f}-\Delta t}{\rho_{b}-\rho_{f}} * 0.01 \\
N=\frac{\varphi_{N f}-\varphi_{N}}{\rho_{b}-\rho_{f}}
\end{gathered}
$$




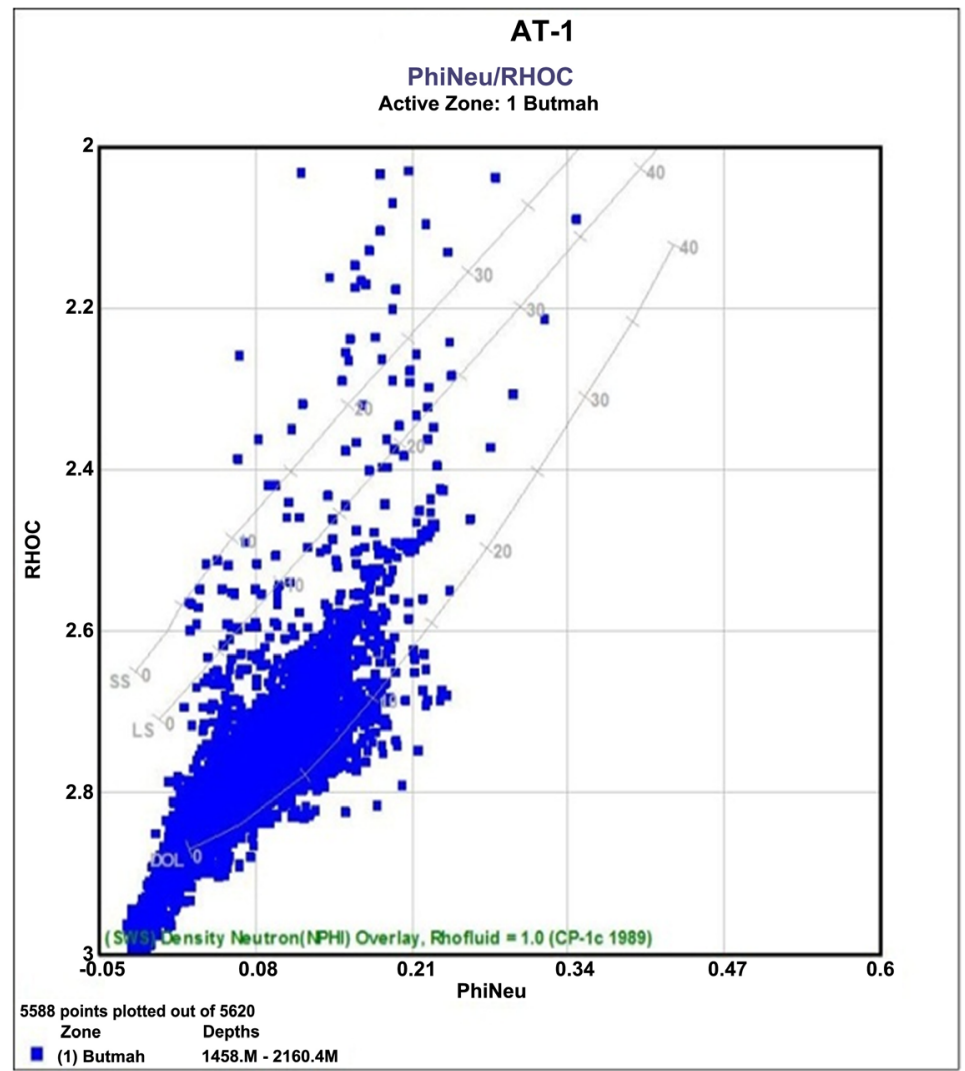

Figure 2. Neutron-Density cross plot for Butmah Formation in well AT-1.

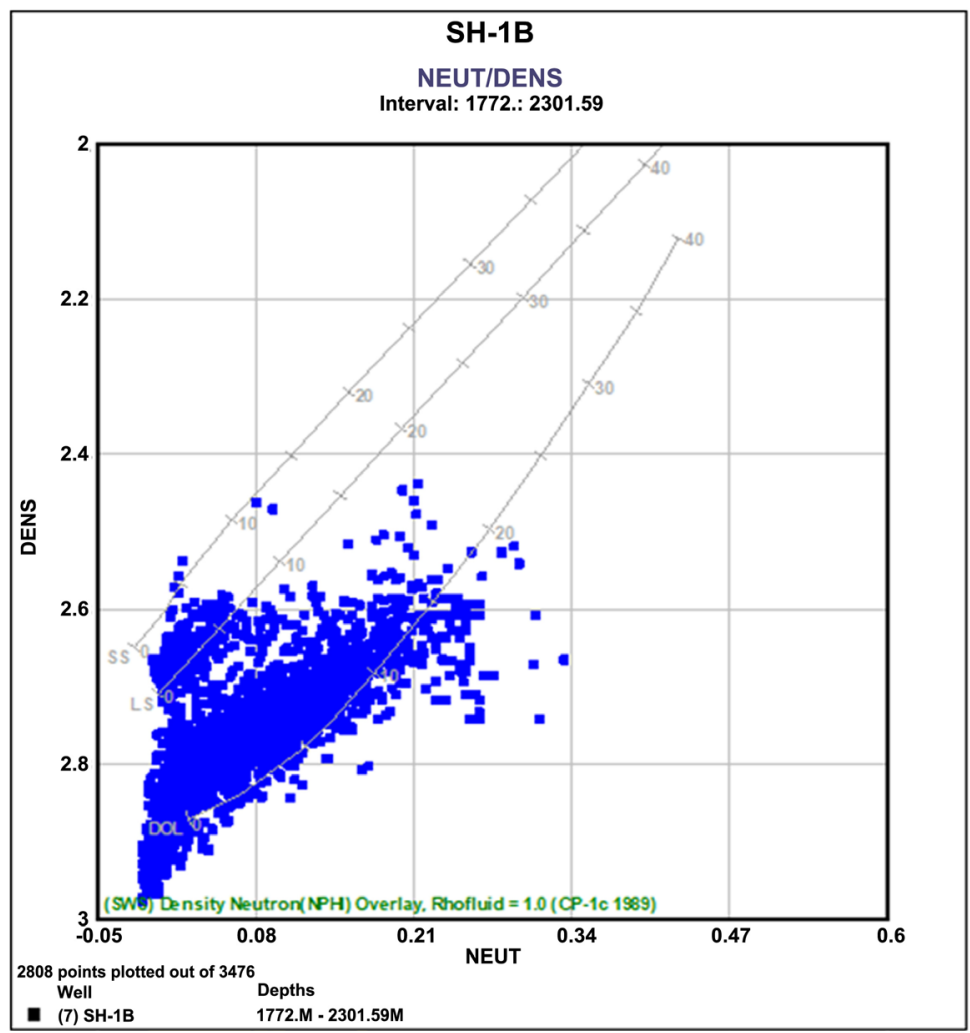

Figure 3. Neutron-Density cross plot for Butmah Formation in well SH-1B. 
where:

$\Delta t_{f}$ Interval Transit Time in the formation fluid, (189 for fresh mud and 185 for salt mud).

$\Delta t$. Interval Transit Time in the formation (from the log).

$\rho_{f}$ : Density of fluid (1.0 for fresh mud and 1.1 for salt mud).

$\rho_{b}$ : Bulk Density of formation (from log).

$\varphi_{N}$ : Neutron Porosity of formation from Neutron Porosity Log.

$\varphi_{N:}$ Neutron Porosity of fluid of formation (use 1.0).

$\mathrm{M}-\mathrm{N}$ cross plot can determine lithology of formation, and is a good indicator of secondary porosity. It is obvious that the lithologic description is matched in both, density-neutron and M-N cross plot methods. Secondary porosity, noticed in Butmah Formation, is enhanced due to tectonic processes that creating local fractures. Figure 4 and Figure 5 represent M-N cross plot in the studied wells.

\subsection{Shale Volume $\left(V_{s h}\right)$ Calculation}

The determination of shale volume $\left(V_{s h}\right)$ would follow several steps. First step is to calculate the Gamma Ray Index (GRI) from the GR log using a formula of Schlumberger (1974), as below:

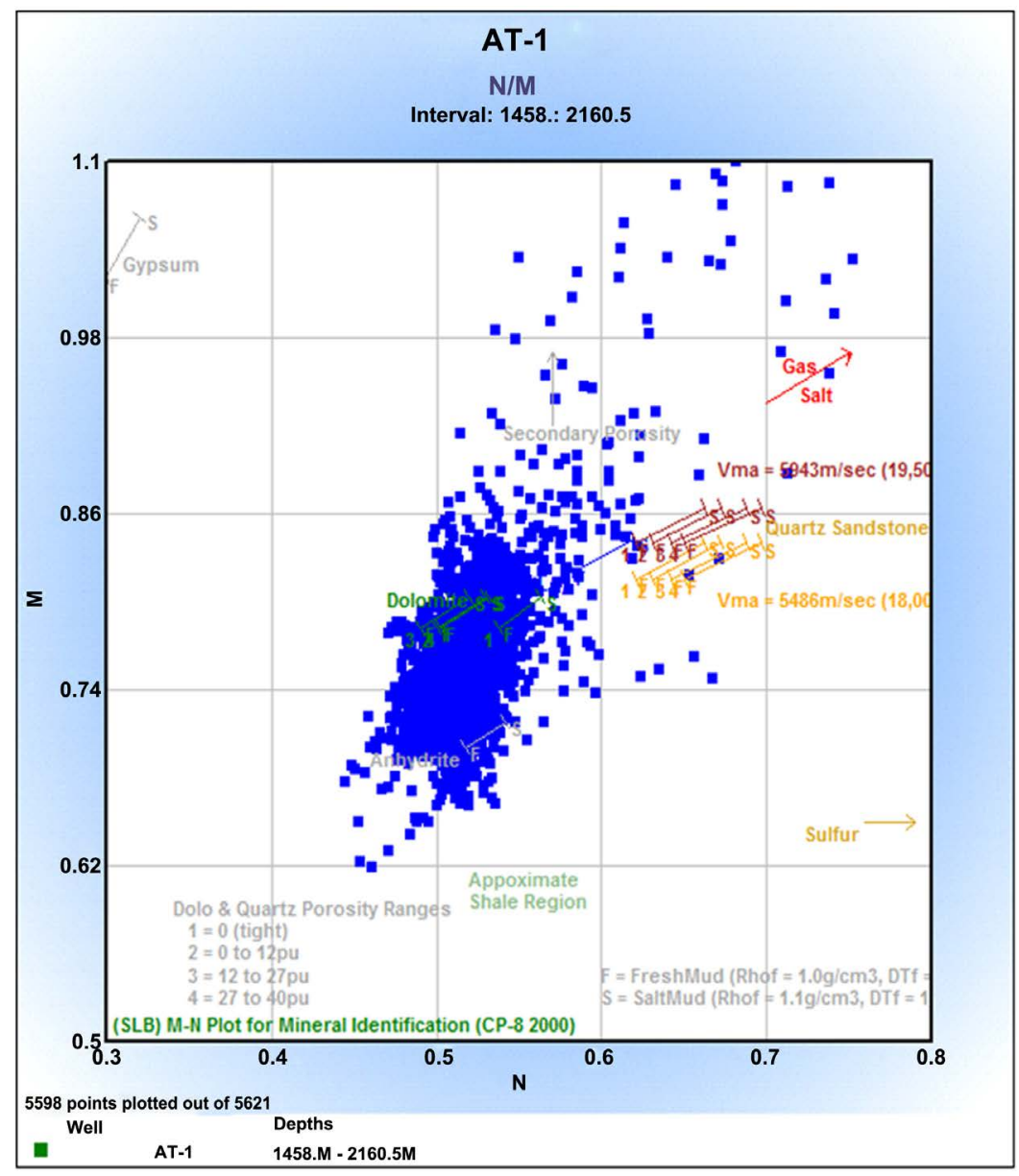

Figure 4. M-N cross plot for Butmah Formation in well AT-1. 


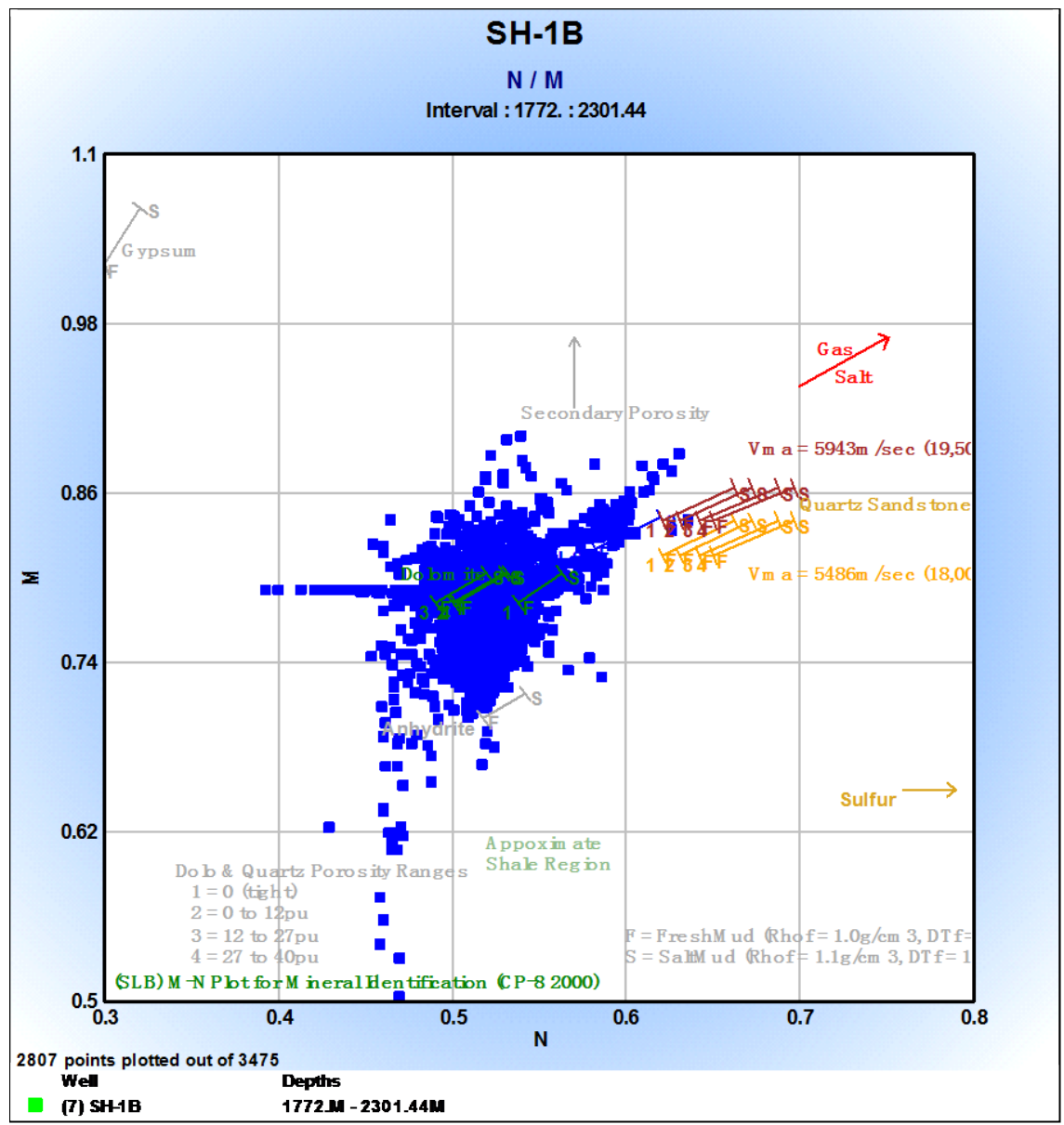

Figure 5. M-N cross plot for Butmah Formation in well SH-1B.

$$
\mathrm{GRI}=\frac{\mathrm{GR}_{\log }-\mathrm{GR}_{\text {min }}}{\mathrm{GR}_{\max }-\mathrm{GR}_{\min }}
$$

Once GRI is calculated, it would be used in the equation of [11] to determine shale volume in older rocks [12]:

$$
V_{\text {sh }}=0.33\left(2^{2 * \text { GRI }}-1\right)
$$

The $\left(V_{s h}\right)$ was calculated for Butmah formation, the results, shown in Figure 6 , Figure 7, were dominantly $<10$. To distinguish between zones of different shale content within the Butmah Formation, the standard range introduced by [13] has been used (Table 2). Consequently, Butmah Formation was found to be a clean formation in both wells.

\subsection{Porosity Determinations from Porosity Logs}

Porosity is defined as the percentage of voids to the total volume of rock. The amount of internal voids or pores is an indicator to the amount of fluids a rock can hold [7].

Connected porosity, where pore spaces are linked, is often called effective porosity, whereas, non-effective porosity refers to isolated pores. The sum of effective 
Table 2. Classification based on the percentage of shale volume (after [13]).

\begin{tabular}{cl}
\hline$V_{s h}(\%)$ & Zone \\
\hline$<10$ & Clean Zone \\
$10-35$ & Shaly Zone \\
$>35$ & Shale Zone \\
\hline
\end{tabular}

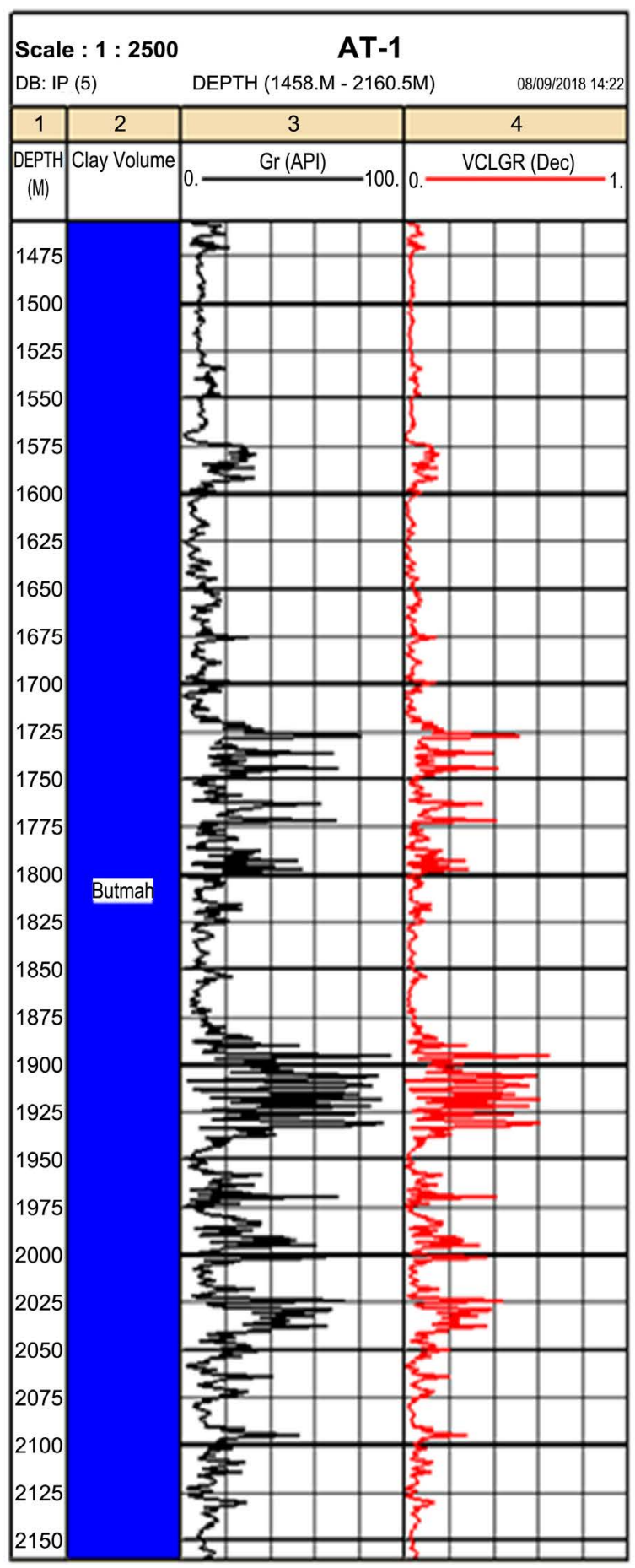

Figure 6. The variation of shale volume with depth in well AT-1. 


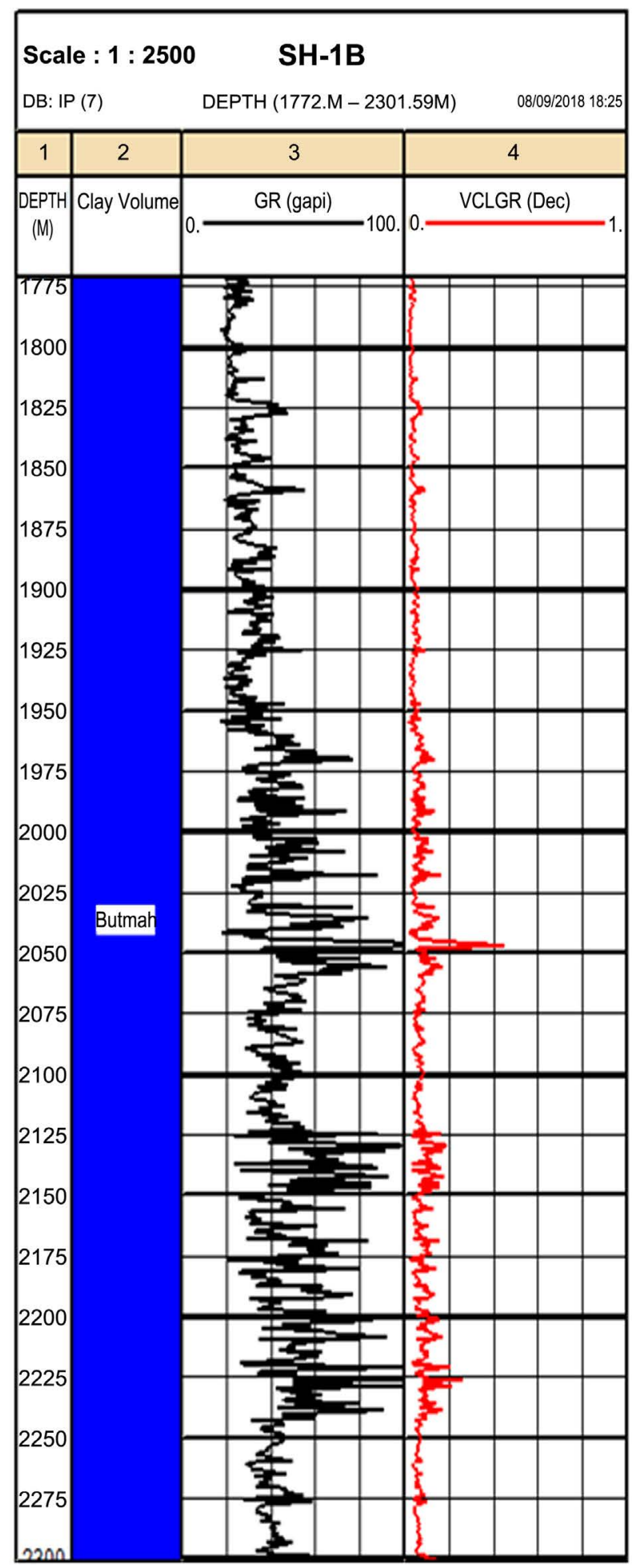

Figure 7. The variation of shale volume with depth in well SH-1B.

and non-effective porosity represents total porosity, which refers to all void space in a rock.

Total Porosity is determined from readings of combined neutron-density logs. This calculation can be implemented by an equation introduced by [12]: 


$$
\varphi_{t}=\frac{\varphi_{N}+\varphi_{D}}{2}
$$

where:

$\varphi_{t}$ : Total Porosity.

$\varphi_{N}$ : Porosity calculated from Neutron Log.

$\varphi_{D}$ : Porosity calculated from Density Log.

Whereas effective porosity $\left(\varphi_{e}\right)$ is calculated from the equation below:

$$
\varphi_{e}=\varphi_{t} *\left(1-V_{s h}\right)
$$

where:

$$
\begin{aligned}
& \varphi_{e}: \text { Effective Porosity. } \\
& \varphi_{t}: \text { Total Porosity. } \\
& V_{s h}: \text { Shale Volume. }
\end{aligned}
$$

Secondary porosity $\left(\varphi_{s}\right)$ is post-depositional porosity; it is commonly calculated through Secondary Porosity Index (SPI) as given by the formula:

$$
\mathrm{SPI}=\varphi_{t}-\varphi_{s}
$$

where:

SPI: Secondary Porosity Index.

$\varphi_{i}$ : Total Porosity.

$\varphi_{s}$ : Sonic Porosity

Figure 8 and Figure 9 display the calculated porosity types and their variation with depth in the studied wells. The total porosity of the formation is calculated using Interactive Petrophysics Program (V3.5) from neutron and density logs and have the average total porosity (8\%) in well AT-1 and (7\%) in well SH-1B.

The difference between the total porosity calculated from these logs and that estimated from sonic log, will give a secondary porosity index, which can be later used to calculate the effective porosity. It is obvious that porosity is varied along the wells; effective porosity decreases in lower part of Butmah Formation in well AT-1 due to shale increase (Figure 8, Figure 9).

\subsection{Fluid Saturation}

Fluid saturation is determined from resistivity log by the Archie's equation. The Archie's Equation [14] is used to calculate water saturation $\left(S_{w}\right)$ of uninvaded zone of a reservoir by the formula:

$$
S_{w}=\left(\frac{a}{\varphi^{m}} * \frac{R_{w}}{R_{t}}\right)^{\frac{1}{n}}
$$

where,

$S_{w}:$ Water Saturation of the Uninvaded Zone.

$R_{w}:$ Resistivity of Formation Water at formation temperature (ohm-m).

$R_{t}$ : True Formation Resistivity (ohm-m).

$\varphi$ : Porosity.

a: Tortuosity Factor $=1.0$. 


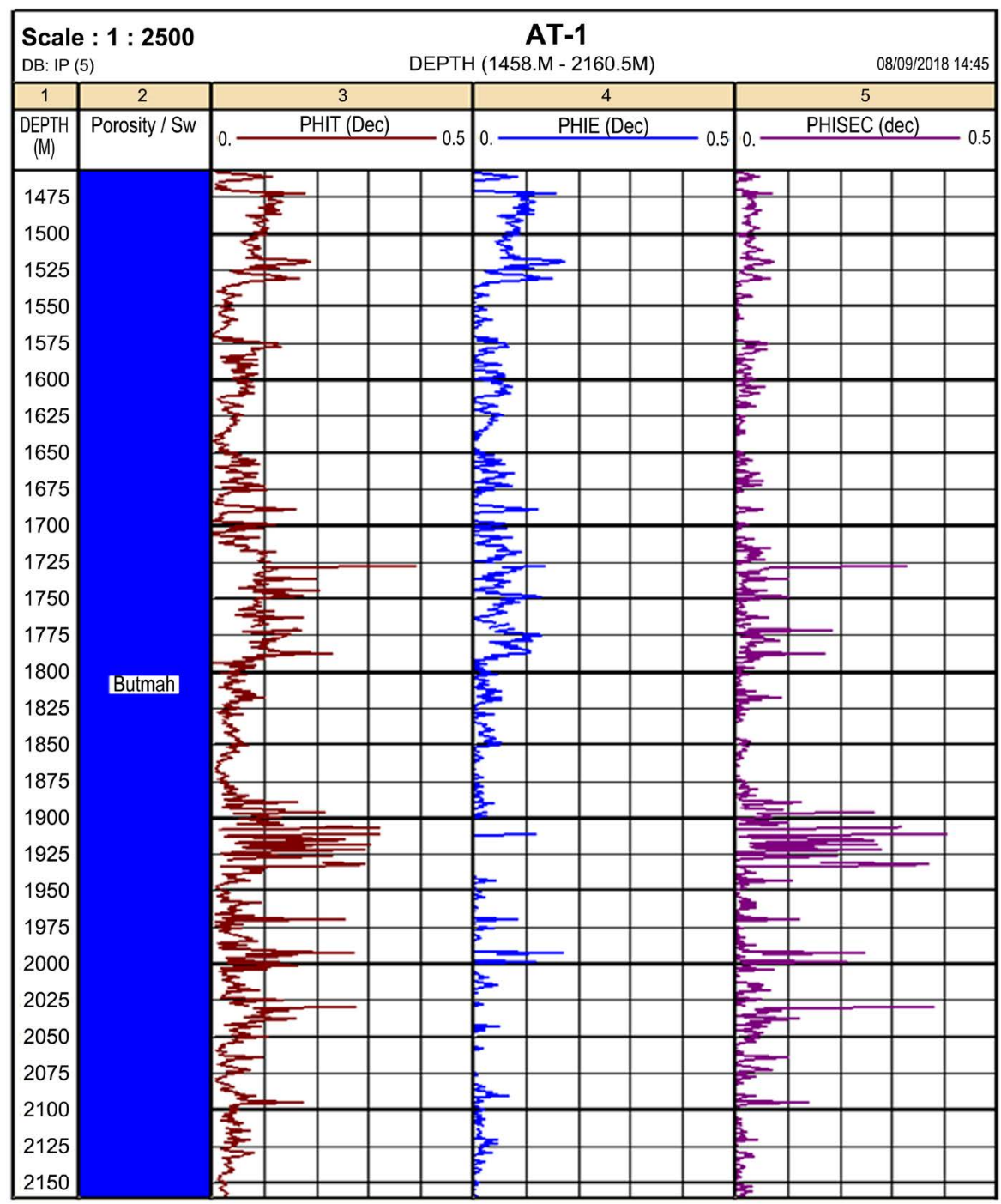

Figure 8. The variation of porosity with depth at well AT-1. ${ }^{\star}$ PHIT (Total Porosity), PHIE (Effective Porosity), PHISEC (Secondary Porosity).

m: Cementation Exponent, ranging from 1.7 to 3.0, normally equal to 2.0.

$n$ : Saturation Exponent, ranging from 1.8 to 4.0, normally equal to 2.0.

The Archie's Equation can be used to calculate water saturation in flushed zone $\left(S_{x o}\right)$, simply via replacing Formation Water Resistivity $\left(R_{w}\right)$ with Mud Filtrate Resistivity $\left(R_{m f}\right)$, and Uninvaded Zone Resistivity $\left(R_{t}\right)$ with Flushed Zone Resistivity $\left(R_{x o}\right)$. Calculation of $\left(S_{x o}\right)$ is given by the equation:

$$
S_{x o}=\left(\frac{a}{\varphi^{m}} * \frac{R_{m f}}{R_{x o}}\right)^{\frac{1}{n}}
$$

Then, hydrocarbon saturation $\left(S_{h}\right)$ would be calculated employing water saturation data via the equation:

$$
S_{h}=1-S_{w}
$$

In the flushed zone, the water saturation can be used to determine the residual 


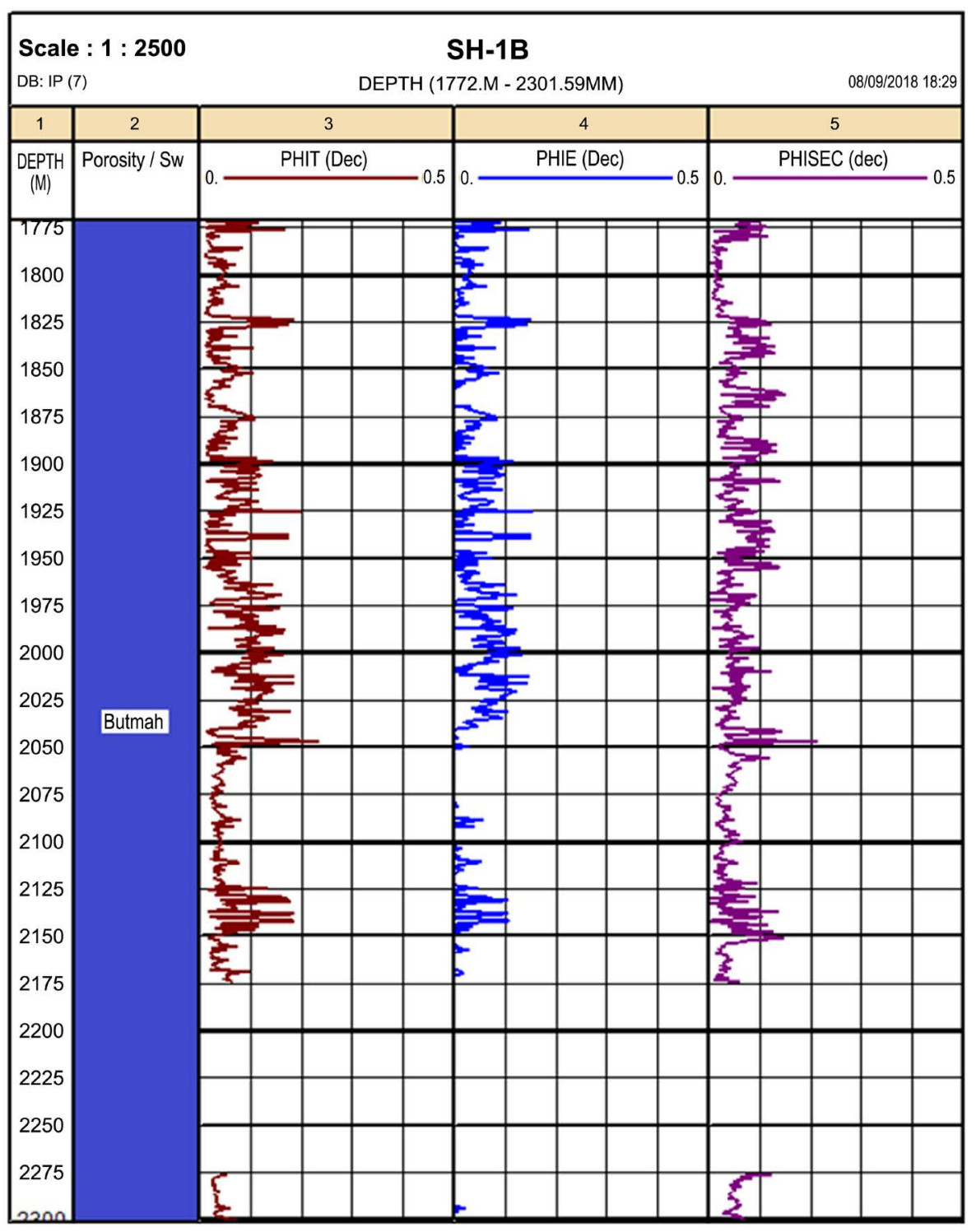

Figure 9. The variation of porosity with depth at well SH-1B. ${ }^{\star}$ PHIT (Total Porosity), PHIE (Effective Porosity), PHISEC (Secondary Porosity).

oil saturation $\left(S_{o r}\right)$ and the movable oil saturation $\left(S_{h r}\right)$ through the formula below [7]:

$$
\begin{gathered}
S_{o r}=\varphi_{e} *\left(1-S_{x o}\right) \\
S_{h r}=\varphi_{e} *\left(S_{x o}-S_{w}\right)
\end{gathered}
$$

The Butmah Formation, in well AT-1, is saturated with $37.2 \%$ water and $62.8 \%$ with oil (residual and movable), while the average value of $\left(S_{w}\right)$ in well SH-1B was $48.2 \%$, leaving $51.8 \%$ for oil. The results of fluid saturation, for the two studied wells, are shown in Figure 10, Figure 11.

\subsection{Bulk Volume of Water (BVW)}

This factor represents water saturation $\left(\mathcal{S}_{w}\right)$ plus porosity $(\varphi)$ of formation [8]. 


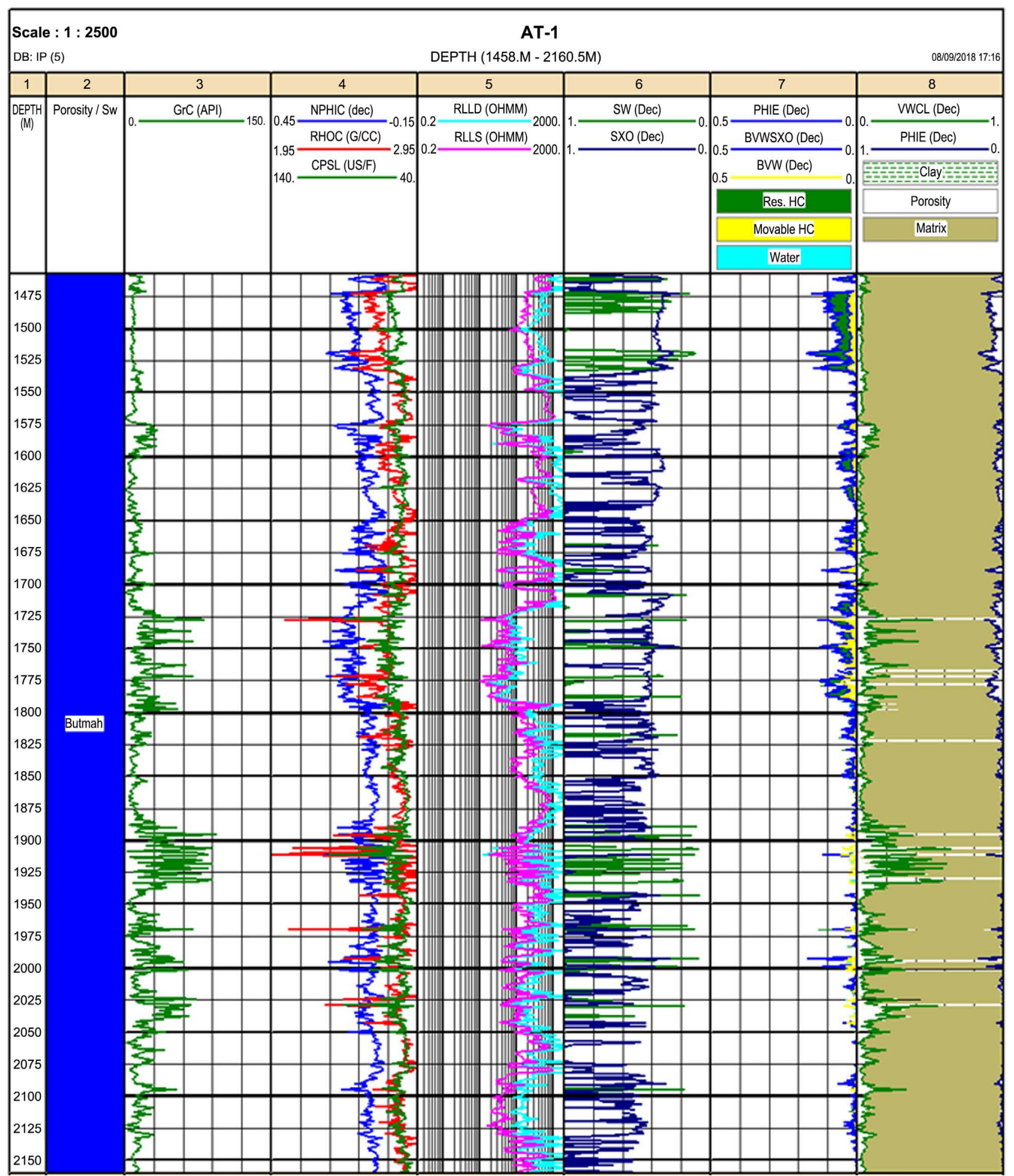

Figure 10. Computer Processed Interpretation (CPI) for the well AT-1.

The BVW is calculated in the flushed and uninvaded zones by multiplying porosity by water saturation [15]:

The BVW in the Uninvaded and Flushed Zones are calculated using Equation (13) and Equation (14), respectively: 


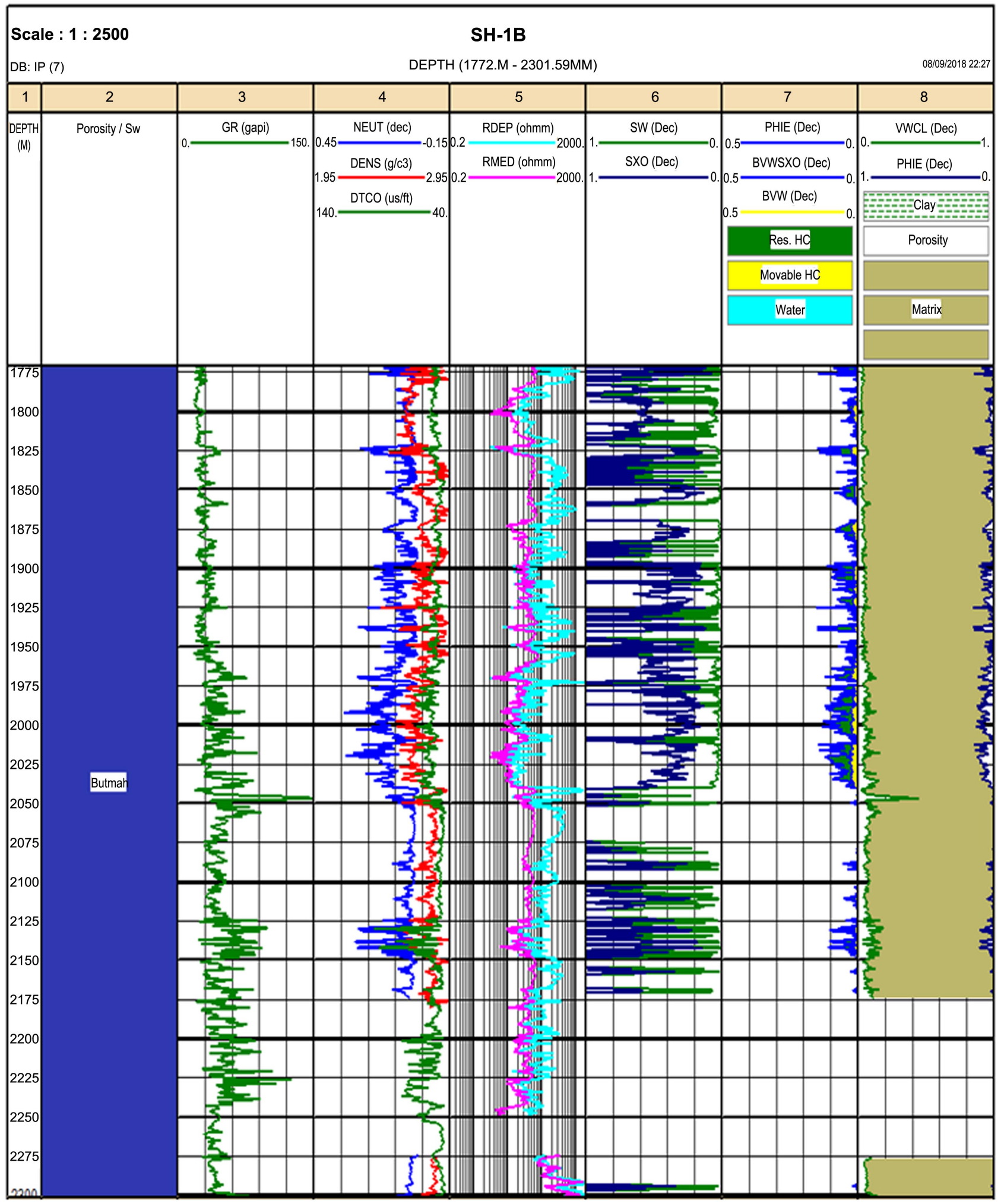

Figure 11. Computer Processed Interpretation (CPI) for the well SH-1B.

$$
\begin{aligned}
\mathrm{BVW} & =\varphi_{e} * S_{w} \\
\mathrm{BVW}_{s x o} & =\varphi_{e} * S_{x o}
\end{aligned}
$$


Figure 10 and Figure 11 describe the relationship of the variables $\left(S_{w}, S_{x o}, S_{o r}\right.$ $S_{h r}, \mathrm{BVW}$, and $\mathrm{BVW}_{s x o}$ ) with depth in the studied wells. Figure 10 and Figure 11 represent Computer Processed Interpretation (CPI), they show observed hydrocarbons in upper part of Butmah Formation in wells AT-1 and SH-1B. Whereas the overlying Adaiyah Formation may create a proper seal for reservoir units in Butmah due to existence of anhydrite beds at the lower part of Adaiyah Formation [6]. Movable hydrocarbon is noticed in both wells, and appears equal to the residual hydrocarbon. In some places, movable is less than residual hydrocarbons which indicate low to medium values of permeability in Butmah Formation in these wells.

\section{Conclusions}

Well logs data of Butmah Formation in wells (AT-1 and SH-1B), have been used to study its petrophysical properties that can designate potential reservoir. From this study, the following conclusions can be drawn:

1) The applied neutron-density and $M-N$ cross plot displayed that dominant lithology in Butmah Formation in the studied wells is dolomite, limestone with anhydrite and shale.

2) The concentration of clay, estimated through GR log, was high in few intervals of Butmah Formation. The concentration of clay, in well SH-1B, was very low. Accordingly, the formation is considered as clean formation in both wells.

3) The average total porosity of Butmah Formation was (8\%) in well AT-1 and (7\%) in well SH-1B. The carbonate lithology of Butmah Formation with such fair porosity values offers potential hydrocarbon reservoir.

4) Water Saturation $\left(S_{w}\right)$ of Butmah Formation, determined by resistivity logs, has average values of $37.2 \%$, leaving $62.8 \%$ for hydrocarbon saturation in well AT-1. Whereas, in well SH-1B, $\left(S_{w}\right)$ was $48.2 \%$, indicating a hydrocarbon saturation of 51.8\%. Therefore, Butmah Formation seems to have potential for a good oil reservoir.

\section{Acknowledgements}

The authors highly appreciate the support from Ministry of Natural Resources (MNR-KRG), in providing the logs sets of Butmah Formation in two wells. Thanks are extended to Salahaddin University-Erbil for their assistance and support during all stages of this research.

\section{Conflicts of Interest}

The authors declare no conflicts of interest regarding the publication of this paper.

\section{References}

[1] Lucia, F.G. (2007) Carbonate Reservoir Characterization: An Integrated Approach. Springer, Berlin, $241 \mathrm{p}$. 
[2] Buday, T. (1980) The Regional Geology of Iraq: Stratigraphy and Paleogeography. Dar Al-Kutub Publishing House, University of Mosul, Mosul, 351 p.

[3] Jassim, S.Z. and Goff, J.C. (2006) Geology of Iraq. Dolin, Prague and Moravian Museum, Brno, 341 p.

[4] Nairn, A.E.M. and Alsharhan, A.S. (1997) Sedimentary Basins and Petroleum Geology of the Middle East. Elsevier Science, Amsterdam, 843 p.

[5] Aqrawi, A.A.M., Goff, J.C., Horbury, A.D. and Sadooni, F.N. (2010) The Petroleum Geology of Iraq. Scientific Press Ltd., London, 560 p.

[6] Sherwani, G.H. and Zangana, H.A. (2017) Reservoir Characterization of Early Jurassic Formations in Selected Wells in the Duhok Governorate, Iraqi Kurdistan Region. UKH Journal of Science and Engineering, 1, 11-18. https://doi.org/10.25079/ukhjse.v1n1y2017.pp11-18

[7] Asquith, G.B. and Gibson, C. (1982) Basic Well Log Analysis for Geologists. AAPG, Tulsa, $216 \mathrm{p}$.

[8] Asquith, G.B. and Krygowski, D. (2004) Basic Well Log Analysis. Second Edition, American Association of Petroleum Geologists, Tulsa, 239 p. https://doi.org/10.1306/Mth16823

[9] Krygowski, D.A. (2003) Guide to Petrophysical Interpretation. 136 p.

[10] Schlumberger (1972) Log Interpretation Manual/Principles. Vol. 1. Schlumberger Well Services Inc., Houston.

[11] Larionov, V. (1969) Borehole Radiometry: Nedra. The SPWLA Annual Logging Symposium Transactions, Vol. 10, 26.

[12] Schlumberger (1974) Log Interpretation Manual/Applications. Vol. 2. Schlumberger Well Service, Inc., Houston.

[13] Ghorab, M., Mohamed, A.M.R. and Nouh, A.Z. (2008) The Relation between the Shale Origin (Source or Non-Source) and Its Type for Abu Roash Formation at Wadi El-Natrun Area, South of Western Desert, Egypt. Australian Journal of Basic and Applied Sciences, 2, 360-371.

[14] Archie, G.E. (1942) The Electrical Resistivity Log as an Aid in Determining Some Reservoir Characteristics. Journal of Petroleum Technology, 146, 54-62. https://doi.org/10.2118/942054-G

[15] Schlumberger (1989) Log Interpretation Principles/Applications. Seventh Printing, Schlumberger Well Service Inc., Sugar Land. 